\title{
The 'Vanaratna Codex': A Rare Document of Buddhist Text Transmission (London, Royal Asiatic Society, Hodgson MS 35)
}

\begin{abstract}
The present article deals with a palm-leaf manuscript that contains multiple texts in Sanskrit language (and one text in Apabhramśa) and is written in Old Bengali script. It is an autograph of - or at least closely associated with the Indian Buddhist Tantric master Vanaratna (1384-1468 CE). The manuscript contains not only texts copied from other manuscripts but also Vanaratna's Sanskrit translations of seemingly orally transmitted texts in Tibetan language, which the Indian master must have received during one of his travels to Tibet. Because hardly any cases are known of translation of Tibetan texts into Sanskrit, the present manuscript is a document of unique historical value. The article gives an overview of the contents of the manuscript, tries to identify the Tibetan master of Vanaratna and provides an introductory discussion of the processes and purposes of adaptation at work here.
\end{abstract}

The multiple-text manuscript dealt with in the present contribution is closely associated with Vanaratna (1384-1468 CE) and his activities. He was a scholar and Buddhist master who belonged to the esoteric-ritualistic, or Tantric, strand of this religion. Vanaratna hailed from the Chittagong district in Eastern India (presentday Bangladesh). After extensive journeys and sojourns in Sri Lanka and various parts of India, including parts of the old heartland of Buddhism in present-day Bihar, he settled down in the Kathmandu Valley in Nepal, where he spent roughly the last four decades of his life. Additionally, he undertook three travels to Tibet during this second half of his life. Vanaratna was not only a key figure in the last chapter of the history of Indian Buddhism, but also attracted followers and acquired great fame in both Nepal and Tibet. In Tibet, he was often designated as the 'last pandit' of Indian Buddhism. ${ }^{1}$ Relatively much information on his life, travels and activities can be gathered from various sources, among which three

1 Pal 1989, 189; Parajuli 2014, 289 (with some further references).

Ә Open Access. (๑) 2021 Martin Delhey, published by De Gruyter. (cc) BY-NC-ND This work is licensed under the Creative Commons Attribution-NonCommercial-NoDerivatives 4.0 International License.

https://doi.org/10.1515/9783110741124-018 
biographies written by Tibetan contemporaries are the most important. ${ }^{2}$ Besides the manuscript dealt with in the following pages, extant cultural artefacts associated with Vanaratna include at least one Tibetan portrait painting. ${ }^{3}$ According to David Jackson, a gilt-copper statue from Tibet can also be identified as portraying Vanaratna, although its inscription poses major problems of interpretation. ${ }^{4}$ Furthermore, there is a particularly significant and fascinating painting from Nepal, ${ }^{5}$ several fifteenth-century grammatical Indian manuscripts that have been copied for Vanaratna, ${ }^{6}$ and another manuscript written in Bengali script, which according to the colophon was commissioned by him. ${ }^{7}$ Moreover, several of his own works are preserved in Sanskrit or/and in a Tibetan rendering, and there are extant translations of works by other Indian authors into Tibetan in which he participated. ${ }^{8}$ There is also the original Sanskrit text of a hymn as well as its Tibetan rendering composed in praise of Vanaratna. ${ }^{9}$ Finally, manuscript copies of four bilingual (i.e. Sanskrit and Tibetan) letters written by Vanaratna's Tibetan disciple Khrims khang lo tsā ba bsod nams rgya mtsho (1424-1482) are extant. The first two were sent to Vanaratna, when he had returned from Tibet to Nepal, whereas the others have been written after Vanaratna's death and are directed to a Nepalese boy who was considered to be Vanaratna's reincarnation. ${ }^{10} \mathrm{bSod}$ nams rgya mtsho also acted as a translator for Vanaratna during his third and last

2 For a list and comments on these three works, see Parajuli 2014, $289 f$.

3 See Ehrhard 2004, 264-265; Jackson 2011, 50-51 and 94-95.

4 Jackson 2011, 96-98.

5 See Vajracharya 1987; Pal 1989, 194-195; Huntington and Bangdel 2003, 143-145; TuladharDouglas 2006, 140. A later copy of this painting is extant as well. For all particulars regarding both the original and the copy see the references above.

6 Hori 2018. Cf. also n. 14 below.

7 Pal 1989, 195-196, where a translation of the colophonic statement that mentions (and praises) Vanaratna can be found. For two further mentions of Vanaratna in Sanskrit manuscript colophons, see Pal 1989, 195, and Szántó 2012, I, 236, n. 59.

8 See Ehrhard 2002a, 113-117 for a list of Vanaratna's translations of works into Tibetan and for an overview of those of his own works that are extant in Tibetan. Some of Vanaratna's works are preserved in the original Sanskrit: in edited form, the Ratnamālāstotra or ${ }^{*}$ Stavaratnamālā (a hymn; see Hahn 1996, 32-34) and the Rahasyadīikikā (a commentary on Kṛṣnācārya's Vasantatilakā; edited in Rinpoche and Dwivedi 1990) are available. Moreover, in manuscript form a work entitled Acalakramadvaya (see Sānkṛtyāyana 1935, no. 162) and the Acalābhisamaya (according to an entry in Péter-Dániel Szántó’s Thor bu - Curiosia Indo-Tibetica Blog, posted 28 Febr. 2010 (<http://tibetica.blogspot.com/2010/02>, accessed on 17 Nov. 2020) seem to be extant. 9 For an edition and German translation of this text see Hahn 1996.

10 For the facsimile edition of the four letters see Ehrhard 2002b; for their transcription and English translation, see Ehrhard 2002a, 101-111. 
journey to Tibet. ${ }^{11}$ However, arguably the most fascinating trace of Vanaratna's activities available to us is the multiple-text manuscript to which the present contribution is devoted.

Our multiple-text manuscript was found in Nepal and is kept since the nineteenth century at the Royal Asiatic Society in London (shelf mark Hodgson MS 35). It contains numerous Old Indo-Aryan, that is to say, Sanskrit, texts as well as one single text in the late Middle Indo-Aryan Apabhramśa language. For a long time, its value remained hidden to the modern scholarly world. This oversight can, among others, be explained by the fact that in their catalogue, the nineteenthcentury Sanskritists Cowell and Eggeling classified this codex erroneously as paper manuscript and as having been written in the end of the eighteenth century. ${ }^{12}$ It was Harunaga Isaacson who has drawn attention to this manuscript and its importance. ${ }^{13}$ He labels it as 'a unique treasure', points out that the writing support is palm leaf rather than paper and that there are reasons to assume that it is the autograph of the Tantric Buddhist master Vanaratna, or has at least been prepared under his close supervision. ${ }^{14}$ As reasons for this assumption, Isaacson adduces the facts that in one place of the manuscript Vanaratna refers to himself in the first person ${ }^{15}$ and that various lineages of teachers who transmitted individual texts are given, and all but one of these lineages end with Vanaratna as final recipient. Moreover, Isaacson deduces from the facts that the manuscript contains several references to Tibetan teachers and to the Tibetan language that the manuscript most probably has been written between 1426 (the date of Vanaratna's first visit to Tibet) and $1468 \mathrm{CE}$ (the year of Vanaratna's death) rather than in the late eighteenth century, as Cowell and Eggeling assumed. ${ }^{16}$ The script

11 Ehrhard 2004, 256.

12 Cowell and Eggeling 1876, 26-28. In the pertinent catalogue entry they do not specify the writing support at all. In the introduction to the catalogue, however, they establish the following rule for such a case: 'The material of the MSS. consists of Indian paper, unless otherwise stated' (Cowell and Eggeling 1876, 1).

13 Isaacson 2001, 460-461; Isaacson 2008 passim.

14 In his discussion of grammatical manuscripts that have formerly been in the possession of Vanaratna, Hori $(2018,46)$ argues that at least some of the marginal annotations in these manuscripts have very likely been written by Vanaratna himself. Moreover, he wonders whether the hand is in these cases the same as in the Vanaratna manuscript. He refers to two plates in his article of which each shows a single folio page with a few annotations. I have the impression that two of these annotations fit very well to the hand of our manuscript. However, this might be a rather subjective impression and should be tested against the testimony of more of these annotations.

15 Cf. n. 26 below.

16 Isaacson 2008, 2-3. 
used in the manuscript is Old Bengali, a fact that seems to corroborate both the fifteenth-century origin and the hypothesis that it is an autograph by Vanaratna. It has already been mentioned above that Vanaratna hailed from the far east of the Indian subcontinent. Even if he has not learnt a form of Old Bengali script there, he certainly came into contact with it at the latest when he spent in his younger years also some time in the area of present-day Bihar. ${ }^{17}$ We have several contemporaneous extant Buddhist Sanskrit manuscripts from this region that have been written in Old Bengali script. ${ }^{18}$

The palm leaves measure $12 \times 2$ inch, which results in the typical oblong format of this writing support. The texts are written with black carbon-based ink. Except for the last two folios, each page contains 10 lines of text. They are written in scriptio continua from left to right and parallel to the oblong sides of the leaves. The blocks of texts are framed by margins on all four sides; some of them contain brief additions and corrections. In lines 4 to 7 of each page a square is cleared for the binding holes. The latter enabled the users to string the palm leaves together. Except for very few notable exceptions - I will return to this matter later - all letters of the manuscript are written in the same peculiar and elegant hand. The folios are numbered in the right margin of the verso sides. New texts begin without the insertion of a line break or page break, as it was usual in North-East Indian and Nepalese palm-leaf manuscripts. The texts are only separated from each other by text colophons, which are highlighted by various kinds of section markers and empty spaces amounting to the breadth of some letters. The manuscript is not preserved completely. The number of extant folios amounts to 62. Some folios are damaged in the right margin, which results in the loss of a certain amount of page numbers and of some letters from the text block.

Regarding the foliation, the manuscript poses some problems, in particular because of the fact that it is a multiple-text manuscript. To begin with, the manuscript text starts on the verso side of page 7. It was usual to leave the first recto side empty, but why does Vanaratna give the number seven rather than the number one to the first folio? A reasonable hypothesis might be that he paginated a certain amount of folios beforehand (at least seven), filled the first six folios with text and, as a second step, gave them away to somebody. Afterwards, when he continued filling the manuscript with text, he did not change his original pagination of folio 7 (or of folio 7 and an unknown number of further folios), but left 7 recto blank in order to indicate the new start of the manuscript. ${ }^{19}$ Unless these

17 Roerich 1976, 797-798; Pal 1989, 189-191.

18 Hori 2015.

19 Oral communication by Harunaga Isaacson. 
folios reappear in the future, we will probably never be able to gain some knowledge about the character and the contents of the first six folios.

The next problem concerns the foliation numbers 51 to 66. Due to damage of the margins of the leaves, these folio numbers are not preserved. However, between fol. 50 and fol. 67 the manuscript only contains six rather than sixteen folios. This can only be due to one of the two following alternative reasons: Either Vanaratna erroneously made an upward jump by ten digits, while adding the folio numbers on the verso sides of the palm leaves, or ten folios in between have been lost. If the latter scenario is the correct one, the only possibility would be the loss of ten folios after fol. 50, because only there the beginning of a new text coincides with a change of folios. However, the text ending on fol. 50 and the one beginning on the next folio are, judging from their titles and their contents, rather closely related, so that it is doubtful whether here really ten folios have been lost. Therefore, I tend to the hypothesis that an erroneous upward jump by ten digits occurred during the foliation of the leaves. A tiny part of the folio number on the first folio after fol. 50 seems to be preserved (namely the top left part), and in my view this fits better to an original number ' 61 ' than to the number ' 51 '. Therefore, I suppose that Vanaratna's error regarding the pagination started here rather than on the later folios. ${ }^{20}$

The last two folios of our manuscript do not bear any foliation. Since the immediately preceding fol. 78 ends abruptly somewhere in the middle of the text Prānāyāmadhāraṇayor Upadeśah., ${ }^{21}$ an unknown number of folios has been lost. Hence, we do not know the real number of these two folios, and I have simply called them ' $A$ ' and ' $B$ '.

After this rather technical, but not unimportant discussion, it is time to move to the contents of the multiple-text manuscript. ${ }^{22}$ The first striking thing one notices when scanning the folios of the manuscript is that we have a colophon typical for manuscript endings somewhere in the middle rather than at the end of the manuscript, namely on fol. $45^{\mathrm{v}}$. Here, the manuscript is declared to be a religious gift (deyadharma) by Vanaratna himself, and he dedicates the religious

20 On the damaged folios, a modern hand (perhaps one of the cataloguers Cowell and Eggeling) has supplied folio numbers with pencil and in Arabic numerals. These folio numbers are not in agreement with my hypothesis. What I call fol. 61, for instance, is designated as ' 51 ' on the manuscript. In the table of contents appended to this contribution, I add the pencil marks in parentheses after my own numbering.

21 This has already been noted by Cowell and Eggeling $(1876,28)$.

22 I will only discuss select aspects here. For a complete table of contents, which contains many items not listed in the catalogue Cowell and Eggeling 1876, the reader may refer to the appendix of this contribution. 
merit derived from producing / writing it to his teachers, parents and all other sentient beings, as it was customary in Buddhist manuscripts, especially in those written by adherents of the altruistic 'Great Vehicle (mahāyāna). ${ }^{23}$ Seemingly, Vanaratna first wanted to end the manuscript on the fol. $45^{\mathrm{v}}$, but changed his mind later on and wrote further texts on palm leaves of the same dimensions. Accordingly, he also went on with his numbering of the folios rather than start with folio number one again.

If we look now at the titles (and partly also the authors) of these texts assembled here, it becomes immediately clear that we are dealing with Buddhist Tantric, i.e. esoteric-ritualistic texts. The Tantric variety of Buddhism was seen by many Indian Buddhists as belonging to the altruistic 'Great Vehicle' mentioned above; the main difference lies in the fact that in Tantric Buddhism it is claimed that the common goal of becoming a buddha can be achieved much faster than in the more conventional 'Great Vehicle.'

In spite of the common Tantric character of all the texts, there is in fact a huge difference between the first few texts and the bulk of all the remaining texts. The first four texts of the manuscript (i.e. the texts found on fol. $7^{\mathrm{v}} 1$ to fol. $47^{\mathrm{r}} 8$, except for the above-mentioned colophon) are presumably simply copied from manuscripts that cannot now be identified and may well no longer be in existence, which Vanaratna might have found either in Nepal or during one of his journeys to Tibet..$^{24}$ Of all these texts we have other Sanskrit manuscripts or at least Sanskrit fragments; therefore, we can be very sure about this. The following texts (i.e. the texts that can be found on fol. $47^{\mathrm{r}} 8$ to fol. $78^{\mathrm{v}} 10$ ) have an entirely different character, and this is also signalled on folio 47 recto with a sudden change of ink; i.e. Vanaratna has not immediately continued to write the second group of texts. We do not know of any other manuscripts containing the wording of any of these texts. At the end of the first text of this second group, Vanaratna himself adds the following verses:

Now [the verses] of another [person]: ${ }^{25}$ The accurate explanation of the meaning of the accomplishment text that has been handed down in the [teaching] lineage and has been

23 See Isaacson 2008, 2 and n. 6; cf. Fig. 1a.

24 Due to the fact that Indian Buddhism was on the decline since several centuries when Vanaratna was born and because of the more favourable cultural and climatic conditions in Nepal and Tibet, these were the two places, where he was most likely to find manuscripts of important old texts.

25 That is to say: Verses written by Vanaratna himself. Immediately before, the manuscript contains verses that Vanaratna has marked by the expression '[verses] of the author of the text' (granthakārakasya). 
well preserved in the country of Tibet in Tibetan language does not accomplish the perfection of welfare of the remaining sentient beings (i.e. the non-Tibetan sentient beings). Desiring that the perfection of the welfare of the whole world may be accomplished and in the wish for the [long] preservation of the Good Teaching, I, the glorious Vanaratna, ${ }^{26}$ have discarded the Tibetan language and duly composed and written this accomplishment text in the Sanskrit language; may those who are intent on the meaning take this up without clinging to the wording. ${ }^{27}$

(aparasya tu $\|$ pāramparyīkrtam siddher nipunam $(!)^{28}$ arthavarṇanam | yad *bhoțavișaye samyak susthitam * bhoțabhāṣayā \| na sādhayati śeșāṇām sattvānām hitasampadam | apy eva nāma sādhyeta $a^{29}$ sarvalokārthasampadam ${ }^{30} \|$ ity evam ābhilāṣeṇa(!) ${ }^{31}$ saddharmasthitikāinkșayā | mayā śrīvanaratnena bhāṣāṃ saṃtyajya *bhoțikām ${ }^{32} \|$ granthitā likhitā samyak siddhih samskṛtabhāṣayā |

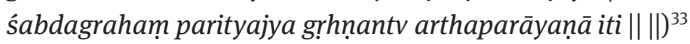

26 Isaacson 2008,8 has already drawn attention to this phrase and adduced it as one of the arguments in favour of his assumption that the manuscript is 'probably an autograph', although he explicitly mentions the possibility that it has only been prepared under Vanaratna's close supervision. The Sanskrit word śrī (translated by me as 'glorious' here) is usually added to names and text titles as a term of respect. In Buddhism, it is, for example, often prefixed to names of deities and titles of scriptures. In the present manuscript it appears before the name 'Vanaratna' in almost all cases, and in one of the rare counter-examples, the respectful suffix ${ }^{\circ} p \bar{a} d a$ is used instead. In my view, which is rather vaguely based on my reading experience, such a way to refer to oneself is not impossible, in particular in Tantric Buddhism. It should be kept in mind that the self-identification with a high-ranking deity in ritual and meditative visualisation is a common practice in this tradition. Therefore, I do not think that the reference to oneself as 'glorious' is a valid argument against the hypothesis that this text is an autograph. However, it would certainly be rewarding to devote a study to the ways of referring to oneself in Buddhist texts.

27 It is a text originally composed in Sanskrit, but Vanaratna only had access to the Tibetan translation. Seemingly, he is well aware of the fact that his back-translation can hardly restore the original wording.

28 Wrong spelling of Sanskrit nipunam.

29 The manuscript reading is sādhyetat rather than sādhyeta. However, above the ending of the word is a mark that possibly signifies cancellation of the final $t$.

30 In this line, Vanaratna seems to use as final member of the compound a neuter word with the stem form sampada rather than the feminine word sampad of classical Sanskrit.

31 Normally, this word should be spelt abhilāșena.

32 See $n$. 34 below.

33 Fol. 50v7-9 (cf. Fig. 1b). Orthography standardized; nipunam and ābhilāṣeṇa have been left unaltered in the text, because they are orthographical mistakes rather than orthographical variants. 
Note that the words referring to Tibet and the Tibetan language ( ${ }^{\star}$ bhoțavișaya, *bhoțabhāssa $\bar{a},{ }^{\star} b h o t i k a^{34}$ ) are reconstructed here. The manuscript in its actual state has in all three places a different, clearly secondary reading; I will come back to this topic later.

In the verses quoted above, Vanaratna leaves no doubt that he has translated this text from Tibetan to Sanskrit (samskṛtabhāsāa). After another text of this second group one finds a similar remark by Vanaratna. ${ }^{35} \mathrm{He}$ specifies the text as having been transmitted in Tibetan and says that he has written it down in the highest language (bhāsottama), which is obviously a reference to Sanskrit, the ancient Indian language used preferably for holy and scholarly texts.

One of these texts is even attributed to an author with a virtually untranslated Tibetan name, namely Ko Brag pa (1182-1261; appearing as kobrakpāda in Vanaratna's $\left.\operatorname{code}^{36}\right)$, and thereby immediately recognizable as being an indigenous Tibetan text. The text itself is, of course, preserved here in Vanaratna's Sanskrit.

Moreover, many of these texts are accompanied by an often very long lineage of teachers (gurupäramparya) through which the respective esoteric instruction has been handed down. Almost all of these texts end with the name Srivivanaratna as final recipient of the text, and the immediately preceding names of text transmitters can, although they usually appear in Sanskrit translation, be identified as referring to Tibetan masters.

One of these lineages has already been analysed by Harunaga Isaacson. The list starts with Indian teachers. However, in at least one case, obviously the Sanskrit name is wrong, and the mistake can best be explained by the fact that Vanaratna has been told the Tibetan translation of the Sanskrit name and simply misheard one vowel. He confused the Tibetan syllable thub with the phonetically very similar syllable thob. This seems to be a clear indication that Vanaratna has translated the lineage of teachers from oral instruction..$^{37}$ In at least one place, he

34 In the usual dictionaries of the Sanskrit language, I have only found the adjective bhotiiy $a$ as equivalent of 'Tibetan', but the reading bhotiiy ām would violate the metre of this verse. However, judging from the vocabulary of some new Indo-Aryan languages, e.g. Nepali (see Turner, 1931, s.v. bhoțiyā), bhoțiyām, which is unproblematic in terms of metric requirements, can be considered as an alternative to the reconstruction as bhoțikām. It would have the advantage that it makes it slightly more easily explainable why all three syllables rather than only the first two have been erased and overwritten with the word deśikām by a second hand. However, the reading bhoțikām sounds somewhat more Sanskritic.

35 Fol. 73v-6.

36 Fol. $75^{\mathrm{v}} 10$.

37 Isaacson 2008, 4. 
apologizes for committing a secret teaching to writing, ${ }^{38}$ thereby implying that he received it in oral form. In view of all these facts, it seems to be reasonable to suppose that Vanaratna has received all texts and lineages of teachers in the second part of the manuscript not only in Tibetan language but also in oral rather than in written form. Most texts seem to go back to former Indian Tantric masters as authors; in a sense one might call them back-translations to Sanskrit, although one should be aware that the texts due to their nature as oral instructions handed down through the centuries from master to master have probably been more or less fluid in character, whereas the term back-translation rather suggests an attempt to regain a text of a solid and invariable nature. Moreover, it has already been mentioned above that at least one text is ascribed to the Tibetan master Ko brag pa. Tibetan origin can perhaps also be postulated for one of the very brief instructions towards the end of the manuscript. There, the author is designated as Sāluguru, which might be Vanaratna's way to refer to ‘a/the master from Zhwa lu' ${ }^{39}$ Zhwa lu is a place in Tibet and seat of a relatively famous monastery.

The last two folios of the manuscript, which are called folios A and B in the present contribution, do not belong to this long section of translations. They contain a verse text written in the late Middle Indo-Aryan language Apabhramśa, and it seems more likely that Vanaratna has found and copied this text either in a Tibetan library or after his return from Tibet in Nepal and supplemented it with interlinear notes and a commentary in Sanskrit. ${ }^{40}$

The present manuscript provides a unique example of intercultural and interlingual transmission and adaptation of knowledge. In particular, it should be noted that the direction of text transfer between India and Tibet has virtually always been of the opposite kind. In a huge translation project covering the period of roughly the eighth to the fifteenth century, the Tibetans have translated thousands of Indian Buddhist texts into their own language. It is no exaggeration to say that they managed in this way to transplant the huge and old tree of Indian Buddhism to their own country. ${ }^{41}$

Until recently, Vanaratna has mainly been known as a transmitter of various circles of esoteric texts and the corresponding Tantric techniques to Tibet rather than as a person, who was actively engaged in a bidirectional exchange of

38 See Isaacson 2008, 3 n. 7.

39 Fol. $78^{\mathrm{r}} 8$.

40 Note, however, that the latter text is called Amarasiddher Särasamgrahah rather than ${ }^{*}$ Amrtasiddher Sārasamgrahah, which suggests some kind of connection to many of the texts translated by Vanaratna from Tibetan (see below).

41 This is, of course, not meant to deny the fact that they also introduced some major changes in the Buddhism they inherited from India. 
knowledge. The contents of the present multiple-text manuscript prove that the latter comes nearer to the truth. Moreover, recently a textual passage has been noted where the fact that Vanaratna received himself initiations into and instructions in esoteric Buddhist texts is mentioned, and it is this textual passage that also seems to solve the problem of the identity of Vanaratna's Tibetan teacher.

Wherever Vanaratna gives a lineage of text transmission in the manuscript with himself as final recipient, he mentions that a master called Ānandamatidhvajaśrïbhadra was the teacher who instructed him in this text. This is a Sanskrit name and must be Vanaratna's translation of his teacher's Tibetan name. Vanaratna treats almost all Tibetan names in the text in this way. Ānandamatidhvajaśrïbhadra is a compound consisting of five different words and forms a Buddhist religious name. Since the Tibetans tended to model their religious names on Sanskrit names and since the Tibetans in their huge translation work created very long lists of exact Tibetan correspondents to Sanskrit technical terms, it is not difficult to uncover the Tibetan original of this name. However, the individual parts of this name are not very specific, and Harunaga Isaacson detected no less than three Tibetan masters from the fifteenth century who can be meant by Ānandamatidhvajaśrībhadra. ${ }^{42}$ Actually, the Tibetans tended to identify the individuals behind these names by means of further specifications referring, for instance, to the region from which a master comes. Thanks to a recent article written by Roberto Vitali, we can now be fairly certain which of the three persons is meant. In this paper, Vitali deals with a relatively littleknown author from the princely Shar kha pa family called Kun dga' blo gros (1365- after 1439). The family hailed from the Eastern Tibetan region of Khams, but moved more to the centre of Tibet, namely to the region of gTsang, more exactly to the area of Upper Nyang, in this period. Kun dga' blo gros calls himself by the full name Kun dga' blo gros rgyal mtshan dpal bzang po in the colophon of one of his works, ${ }^{43}$ and this is the exact Tibetan equivalent of Ānandamatidhvajaśrībhadra. Moreover, Vitali quotes a passage in which it is related that pan chen Nags rin, i.e. 'the great pandit Vanaratna', received many oral instructions from this Tibetan master. ${ }^{44}$

The identification of Vanaratna's teacher Ānandamatidhvajaśrībhadra with Shar kha pa Kun dga' blo gros also fits very well with the testimony of other historiographical sources gathered by Franz-Karl Ehrhard in his article on

42 Isaacson 2008, 5.

43 Vitali 2015, $515 \mathrm{n}$. 3. I am indebted to Mr. Sonam Spitz for drawing my attention to this article. 44 Vitali 2015, 517 n. 6. Several of these instructions are mentioned by name in this source, but I was not yet able to identify any of them with one of the texts in Vanaratna's autograph. 
Vanaratna's three journeys to Tibet. During Vanaratna's first two travels (1426 and 1433-1436) he met the local ruler Rab brtan Kun bzang 'phags pa (1389-1442) in Upper Nyang. During his first visit he stayed two times in the town of rGyal [mKhar] rtse, the ruler's place of residence. In undertaking his second journey to Tibet, Vanaratna even followed an invitation by Rab brtan Kun bzang 'phags pa. ${ }^{45}$ The latter was none other than the nephew of Shar kha pa Kun dga' blo gros. Vanaratna's Tibetan teacher was almost 20 years older than Vanaratna, but according to Vitali his year of death 1429 given by one historical source is wrong. He was definitely still alive during Vanaratna's second journey. ${ }^{46}$ Kun dga' blo gros resided as abbot in the monastery of rTse chen, a place that is not far away from the town of rGyal [mKhar] rtse. The information we have about Vanaratna's sojourns in Upper Nyang and his interaction with members of the Shar kha pa family seems to narrow down the period in which the Vanaratna Codex was written to the period of $c .1426-1436 .^{47}$

Regarding the nature of the texts translated by Vanaratna, it is conspicuous that many of them are concerned with a set of Buddhist Tantric techniques labelled as 'supernatural accomplishment for [becoming] an immortal (amarasiddhi)'. There is a (hitherto unedited) Sanskrit text which contains this set of techniques and bears it in its title, namely the Amrtasiddhi ('Supernatural Accomplishment of Immortality'). The difference in wording is a good example for the difficulties Vanaratna faced in translating instructions that ultimately originated in India. Vanaratna has, of course, received the text names in Tibetan and has, in terms of historical truth, chosen the wrong back-translation to Sanskrit. The word amrta is a polyvalent term and is, accordingly, translated in various ways in Tibetan. One of the possible translations is 'chi med, and actually, this translation is attested in the Tibetan rendering of the word amrtasiddhi. The term 'chi med, however, can also be a rendering of the Sanskrit word amara. Obviously, Vanaratna never encountered a copy of the Buddhist Sanskrit text called Amrtasiddhi or other texts belonging to the same text cycle. In an article that has just been published, James Mallinson deals with the original Amrtasiddhi. He argues that it is the earliest text that contains a whole set of teachings belonging to a certain kind of yoga, namely the so-called hațhayoga, which is still well-known in modern India. Actually, '[t]he modern yoga widely

45 Ehrhard 2004, 248-249.

46 Vitali 2015, 518.

47 In my view, it is more likely that it was written during Vanaratna's second visit to Tibet, i.e. between 1433 and 1436 (see below). 
practiced around the world today is derivative of Hatha Yoga [...]'.48 Usually, it has been supposed that this Yoga originated in Hindu circles, but at least the first codification of its central and typical techniques seemingly happened in a Buddhist Tantric milieu. ${ }^{49}$ In view of the fact that research on hathayoga as a historical phenomenon has only recently come of age, it may be appropriate to define it here in the words of James Mallinson, who is doubtlessly one of the leading experts in this field:

The word hațha (lit. force) denotes a system of physical techniques supplementary to yoga more broadly conceived; Hațha Yoga is yoga that uses the techniques of hața. Hatha Yoga is first referred to by name in Sanskrit texts dating to around the 11th century CE, but some of its techniques can be traced back at least a thousand years earlier, to the epics and the Pali canon. Why these techniques were called hatha is not stated in the texts that teach them, but it seems likely that, originally at least, they were called thus because, like tapas (asceticism), with which they were associated, they were difficult and forced their results to happen. ${ }^{50}$

In the part translated by Vanaratna from Tibetan, there seem to be no theoretical discussions of doctrinal, philosophical or other scholarly problems. At any rate, this section is mainly characterized by an assemblage of religious texts in which many practical instructions are given, how partly mundane, partly religious goals can be attained. Among these techniques, physical postures and Tantric physiology often come into play. Not only in hațhayoga but in Tantric Buddhism in general, the mortal body, which has been connoted rather negatively in earlier Buddhism, becomes a means to achieve higher ends. Perfecting the body even is an acceptable goal in itself. Physical (and mental) wellbeing, especially freedom from ailments, immortality of the body and mind, or the attainment of supernatural powers are repeatedly mentioned as goals of certain practices. One instruction has the objective to lead one to a good rebirth, as is already indicated by the title. ${ }^{51}$ However, very often and in prominent places of the texts, the ultimate soteriological goal of becoming a buddha in this very life is mentioned. ${ }^{52}$

The adaptation processes, which the instructions underwent in Vanaratna's translation, are hard to uncover in detail. Even when one manages to find similar

48 Mallinson 2011, 771.

49 Mallinson 2020.

50 Mallinson 2011, 770.

51 Fols 777-78 2: Sugatyupapattyupadeśa ('Instruction on Rebirth in a Good Existence') or Maraṇakșane Sugatiprāptyupadeśạ ('Instruction on the Attainment of a Good Existence in the Moment of Death').

52 See e.g. fols $47^{r} 9,50^{v} 5$ (cf. Fig. 1b), 61(51) $)^{r} 1,68^{r} 4$. 
instructions among the transmitted Tibetan texts, because someone, like Vanaratna has done, has committed them to writing, one can, due to the fluidity of the texts, never be sure about the exact contents of the instructions of Vanaratna's teacher himself, although the fact that his teacher seemingly has been identified now (see above), makes it possible that we find one of his own oral instructions in written form somewhere. Nevertheless, the discovery and comparison of similar texts as handed down by different teachers remains a desideratum. One of the texts, the Salākapañcaka, has already been treated in this manner within the framework of an MA thesis. ${ }^{53}$

Another problem concerns the fact that we have identified Vanaratna's teacher by now, but do not know much about the exact circumstances of the translation and writing process. It is, for instance, not clear, how good Vanaratna's own Tibetan language proficiency was. It is almost certain that he had some knowledge of Tibetan. As mentioned above, he is said to have participated in the translation process of various Sanskrit texts into Tibetan, and Isaacson has, as mentioned above, shown that at least once he has obviously misheard one of the Tibetan names in a lineage of teachers communicated to him, which resulted in a wrong back-translation of the name into Sanskrit. ${ }^{54}$ However, we know that at least during Vanaratna's first visit to Tibet, the fact that no interpreter was available, was a major impediment to one or the other activity of Vanaratna. ${ }^{55}$ During his second visit to Tibet, he was welcomed in Upper Nyang by a Tibetan interpreter, ${ }^{56}$ and it is, in my view, likely that he received the instructions during this visit and that the new interpreter accompanied him on this occasion. The fact that Vanaratna obviously still needed a translator during his third and last journey to Tibet, ${ }^{57}$ makes it not very likely that he would have been able to translate the oral instructions during the second visit without any help.

On a more general level, many features of Vanaratna's adaptation process can, of course, be gathered from the manuscript itself. Interesting is certainly the fact that he also noted down the lineage of teachers who transmitted the text in the case of all major works. Admittedly, to give teaching and initiation lineages is not unknown outside of Tibet, but in Tibet this habit rose to paramount importance. These lineages of teachers, which were, if possible, traced back to India or even the putative author, were important for the Tibetans to show the

53 Spitz 2015.

54 Isaacson 2008, 4.

55 See Ehrhard 2004, 246 and 248.

56 Ehrhard 2004, 249.

57 Ehrhard 2004, 255. 
authenticity of certain teachings, the more so, when they were handed down orally and/or esoteric in nature. Obviously, Vanaratna regarded this as a feature, which should not be omitted from his manuscript. It is also interesting that Vanaratna clearly tried to render each and every name into Sanskrit, although he made some exceptions. In the case of the Indian teachers, the back-translations were sometimes wrong, and the translations of the names of original Tibetan teachers partly result in rather strange Sanskrit compounds. Moreover, his teacher seemingly sometimes called one and the same Tibetan person differently, that is, he omitted one or the other part of the full name. At least, this is the most probable reason for the fact that the lineages sometimes contain different names, when one and the same person must be meant. Why has Vanaratna taken these troubles to translate all names? Perhaps he thought, even names of Tibetan masters should appear, if possible, in the highest language (bhāșottama), as he calls Sanskrit in one place of the manuscript. ${ }^{58}$ However, it is also possible that he did not see any chance to differentiate clearly between Indian and Tibetan teachers, because all names were obviously given to him in Tibetan, anyway.

Regarding the reasons for his translation work, he adduces himself that these texts should be translated in order that all sentient beings can learn the salvific teachings and that the Good Teaching (saddharma; i.e. Buddhism) can survive longer. Reasons like this for activities like composing or copying texts are stereotypically adduced throughout Indian Buddhist literature. However, I see in this case no reason to suspect that Vanaratna pays only lip-service. In the case of the first reason, he also adds that in Tibetan language it cannot be helpful for the remaining sentient beings, and one can very well imagine that he also has the fact in mind, that there have always only been very few Tibetans in the world. There is also good reason to express the wish that the Good Teaching should remain in the world. The Buddhists always entertained the idea that Buddhism will become extinct one day, but in the case of fifteenth century India, this threat was very real. At this time, there were only very few Buddhists left in the native country of this religion. It is also very well-known that Vanaratna had followers in Nepal, probably even very many, so he must have thought that he will have the opportunity to transmit these teachings further, although there seems to be no positive evidence that he did so. The manuscript contains no marginal annotations in a second hand, and to the best of my knowledge, there are no later copies of the manuscript or of some texts contained in it. Certainly, Vanaratna regarded these texts as useful for his own practice, too. As has been argued above, he seemingly did not know anything about the set of techniques called

58 Fol. $73^{\mathrm{v}} 5$. 
amrtasiddhi, but obviously, he found it interesting enough to translate several texts on this topic and had no doubts about their authenticity.

Finally, one further thing should be noted, which can, if one likes, also be regarded as some kind of adaptation of the Vanaratna Codex to one's own needs, though a very peculiar one, which hardly belongs to adaptation processes as they are usually encountered in teaching and learning contexts. I have mentioned above that several words referring to Tibet and the Tibetan language have secondarily been changed in verses that are found on fol. $50 \mathrm{v} .{ }^{59}$ In another place of the manuscript, a reference to Tibetan language has remained unaltered. ${ }^{60}$ The latter fact as well as the remaining traces of the original letters in the other three places strongly suggest that the original text really contained several explicit references to Tibet. The changes have been made by a second, clearly Nepalese hand. The references to Tibet were replaced by words meaning 'region' or 'local language'. Moreover, in yet another place Vanaratna seemingly referred to his own place of origin but here the letters have been erased so thoroughly that even with the use of modern technique (i.e. with the help of multi-spectral imaging) they could not be retraced anymore. ${ }^{61}$ Obviously, one Nepalese wanted to disguise both the fact that Vanaratna, who was highly revered in Nepal, received teachings in Tibet and the fact that Vanaratna was not a Nepalese by birth. This is the way how Nepalese Buddhism and history comes into play in this unique manuscript as well. It is hard to tell why exactly the manuscript has been manipulated in this way. However, if it is true that the fifteenth century was a period of major political and religious rivalry and change, and if Vanaratna really was 'a bone of contention for several Himalayan polities' one can certainly imagine scenarios, which make the disguise of both Vanaratna's Indian origin and indebtedness to Tibetan Buddhists a logical step. ${ }^{62}$ It would certainly be interesting if specialists in Nepalese Buddhism and history were to think about this problem.

\section{Acknowledgements}

The findings presented in this article are the result of research at SFB 950 'Manuscript Cultures in Asia, Africa and Europe', which was generously funded by the German Research Foundation (DFG) until the year 2019, and part of the research work undertaken at the Centre for the Study of Manuscript Cultures, University of Hamburg. My sincere thanks are due to Professor Harunaga Isaacson for

59 Cf. Fig. 1b.

60 Fol. 73느 (sambhoțabhāṣānugam).

61 Fol. $45^{\mathrm{v}} 10$. Cf. Fig. $1 \mathrm{a}$.

62 See Tuladhar-Douglas 2006, 120 and passim. 
comments on one of the last drafts of the present article as well as pertinent presentations and advice given by him, when the research at the Centre for the Study of Manuscript Cultures was still ongoing. I am also greatly indebted to Shandong University. A position attained at this institution in 2019 enabled me to write the present contribution on the basis of my previous findings. Last but not least, I would like to express my gratitude to the Royal Asiatic Society in London, especially to its librarian Ed Weech. Thanks to the graciousness of this institution, in 2016 we were able to examine their treasures first-hand and to take photographs with our sophisticated scientific devices.

\section{References}

Cowell, Edward Byles and Julius Eggeling (1876), 'Catalogue of Buddhist Sanskrit Manuscripts in the possession of the Royal Asiatic Society (Hodgson Collection)', The Journal of the Royal Asiatic Society of Great Britain and Ireland (new series), 8: 1-52.

Ehrhard, Franz-Karl (2002a), Life and Travels of Lo-chen bSod-nams rgya-mtsho, Lumbini: Lumbini International Research Institute [LIRI].

Ehrhard, Franz-Karl (ed.) (2002b), A Buddhist Correspondence: The Letters of Lo-chen Bsodnams rgya-mtsho, Facsimile Edition of a $15^{\text {th }}$ Century Tibetan Manuscript with an Introduction, Lumbini: Lumbini International Research Institute.

Ehrhard, Franz-Karl (2004), 'Spiritual Relationships Between Rulers and Preceptors: The Three Journeys of Vanaratna (1384-1468) to Tibet', in Christoph Cüppers (ed.), The Relationship Between Religion and State (chos srid zung 'brel) in Traditional Tibet: Proceedings of a Seminar held in Lumbini, Nepal, in March 2000 LIRI (Seminar Proceedings, 1), Lumbini: LIRI, 245-265.

Hahn, Michael (1996), 'Das Vanaratnastotra des Āditya', in Michael Hahn et al. (eds), Suhṛllekhāh: Festgabe für Helmut Eimer, Swisttal-Odendorf: Indica et Tibetica Verlag, 29-42.

Hori, Shin'ichirō (2015), 'Evidence of Buddhism in 15th Century Eastern India: Clues from the Colophon of a Kālacakratantra Manuscript in Old Bengali Script', Indogaku Bukkyōgaku Kenkyū 『印度學佛學學研究』(Journal of Indian and Buddhist Studies), 63/3: 228-234. Hori, Shin'ichirō (2018), 'In the Wake of a Buddhist Monk in $15^{\text {th }}$-Century Eastern India: The Manuscripts of Sanskrit Grammatical Texts Originally Owned by Vanaratna', Bulletin of the International Institute for Buddhist Studies, 1: 45-60.

Huntington, John C. and Dina Bangdel (2003), The Circle of Bliss: Buddhist Meditational Art, Chicago, Columbus (Ohio): Serindia Publications and Columbus Museum of Art.

Isaacson, Harunaga (2001), 'Ratnākaraśānti's Hevajrasahajasadyoga (Studies in Ratnākaraśānti's Tantric Works I)', in Raffaele Torella (ed.), Le Parole e i Marmi: Studi in Onore di Raniero Gnoli nel suo $70^{\circ}$ Compleanno, Rome: Istituto Italiano per l'Africa e l'Oriente, 457-487.

Isaacson, Harunaga (2008), 'Himalayan Encounter: The Teaching Lineage of the Marmopadeśa', manuscript cultures, 1: 2-6.

Jackson, David (2011), Mirror of the Buddha: Early Portraits from Tibet, New York: Rubin Museum of Art. 
Mallinson James (2011), 'Hațha Yoga', in Knut A. Jacobsen et al. (eds), Brill's Encyclopedia of Hinduism, vol. 3, Leiden: Brill, 770-781.

Mallinson, James (2020), 'The Amrtasiddhi: Hațhayoga's Tantric Buddhist Source Text', in Dominic Goodall et al. (eds), Śaivism and the Tantric Traditions: Essays in Honour of Alexis G.J.S. Sanderson, Leiden: Brill, 409-425.

Pal, Pratapaditya (1989), 'The Last Buddhist Pundit of Bengal', in Debala Mitra and Gouriswar Bhattacharya (eds), Studies in Art and Archaeology of Bihar and Bengal, Delhi: Sri Satguru Publications, 189-197.

Parajuli, Punya Prasad (2014), 'Vanaratna and His Activities in Fifteenth-Century Nepal', in Benjamin Bogin and Andrew Quintman (eds), Himalayan Passages: Tibetan and Newar Studies in Honor of Hubert Decleer, Boston: Wisdom Publications, 289-300.

Rinpoche, S. and V. Dwivedi (eds) (1990), Vasantatilakā of Caryāvratī Śrīkṣṣnācārya with Commentary: Rahasyadīpikā by Vanaratna, Sarnath: Central Institute of Higher Tibetan Studies.

Roerich, George N. (tr.) (1976), The Blue Annals, Parts 1 and 2, 2nd edn, Delhi: Motilal Banarsidass.

Sānkṛtyāyana, Rāhula (1935), 'Sanskrit Palm-leaf Mss. in Tibet', Journal of the Bihar and Orissa Research Society, 21/1: 21-43.

Spitz, Sonam (2015), A Critical Edition of the Śalākapañcakam Found in the Vanaratna Codex with Tibetan Parallels and Translation, MA thesis, University of Hamburg.

Szántó, Péter-Dániel (2012), Selected Chapters from the Catușpīṭhatantra, 2 vols, PhD thesis, Oxford University.

Tuladhar-Douglas, Will (2006), Remaking Buddhism for Medieval Nepal: The fifteenth century reformation of Newar Buddhism, Routledge: London and New York.

Turner, Ralph Lilley (1931), A Comparative and Etymological Dictionary of the Nepali Language, London: Kegal Paul, Trench, Trubner \& Co.

Vajracharya, Gautam (1987), 'An Interpretation of Two Similar Nepalese Paintings: In the Light of Nepalese Cultural History', in Niels Gutschow and Axel Michaels (eds), Heritage of the Kathmandu Valley: Proceedings of an International Conference in Lübeck, June 1985, Sankt Augustin: VGH Wissenschaftsverlag, 29-42.

Vitali, Roberto (2015), 'The Book of Names of Nyang stod bla ma-s: Masters and Events of the Years 997-1354', Revue d'Études Tibétaines, 31: 511-576.

\section{Appendix: Table of contents of the Vanaratna Codex}

\begin{tabular}{ll} 
fol. $7^{\mathrm{v} 1} 1-40^{\mathrm{r} 3} 3$ & Amṛtakaṇikā nāma Śrīnāmasaṃgītițippaṇī; copied text \\
fol. $40^{\mathrm{r}} 3-45 \mathrm{r}$ & Abhișekanirukti (by Sujayaśrīgupta), copied \\
fol. $45^{\mathrm{r}} 4-45^{\vee} 9$ & Hevajrasahajasadyoga (by Ratnākaraśānti), copied \\
fol. $45^{\vee} 9-10$ & colophon, donor formula etc. typical for manuscript endings \\
fol. $46^{\mathrm{r}} 1-47^{\mathrm{r}} 8$ & Pañcakramopadeśa (by Ghaṇtā̄āda), copied \\
\hline
\end{tabular}


fol. $47^{\mathrm{r}} 8-50^{\mathrm{v}} 10$

Amarasiddhiyantrasya Sūryaprabho nāma Guruhastagrāhaḥ (by Vīryasiṃha); translation

50 7-9 Vanaratna's verses on his work of (back-)translation

50v9-10 lineage of teachers (gurupāramparya)

fol. 61(51) $1-63(53)^{\mathrm{r} 1} \quad$ (Śrīmad-)Amarasiddhiyantraka (by Prajñāsiṃha); translation

63(53) 1 lineage of teachers (gurupāramparya)

fol. $63(53)^{\mathrm{r}} 1-65(55)^{\mathrm{v}} 7$

Mahad Amarasiddhiyantram (by Virūpākṣa); translation

fol. $65^{\mathrm{v}} 8(55)-68^{\mathrm{r}} 4$

$65(55)^{v} 6-7$ lineage of teachers (gurupāramparya)

fol. 65 '8(55) -684

Marmopadeśa (by Nāropāda); translation

68 2-4 lineage of teachers (gurupāramparya)

fol. $68^{\mathrm{r}} 4-73^{\mathrm{v}} 6$

Śalākapañcaka; translation

68 $8^{\mathrm{r}} 4-9$ lineage of teachers (gurupāramparya; as introductory narrative)

73ㄷ-6 Vanaratna dedicates the merit gained by translating the text into Sanskrit to the attainment of buddhahood by all sentient beings.

fol. $73^{\mathrm{v}} 6-75^{\mathrm{v}} 10$

fol. $76^{\mathrm{r} 1} 1-76^{\mathrm{v}} 1$

(Haḥ-)Ālambanasamudra (by Kobrakpāda [i.e. Ko brag pa]); translation

Marmopadeśa (by Ḍombīheruka); translation

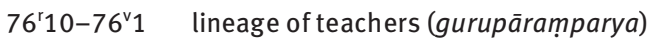

fol. $76^{\vee} 2-77^{15} 5$

Rāgamārgopadeśa (by Indrabhūti); translation

77'3-5 lineage of teachers (gurupāramparya)

fol. $77^{\mathrm{r}} 5-77^{\mathrm{r}} 7$

Cūṣaṇopadeśa (by Ḍombīheruka); translation

fol. $77^{\mathrm{r}} 7-77^{\mathrm{v}} 7$

fol. $77^{\mathrm{v}} 7-78^{\mathrm{r}} 2$

fol. $78^{r} 2-78^{r} 5$

fol. $78^{\mathrm{r}} 6$

fol. $78^{\mathrm{r}} 7-78^{\mathrm{r}} 8$

fol. $78^{\mathrm{r}} 8$

fol. $78^{\mathrm{r}} 8-78^{\mathrm{r}} 9$

fol. $78^{\mathrm{r}} 9-78^{\mathrm{v}} 10$

fol. $A^{r}-A^{v}$

Vāyukarman (by Goputra); translation

Sugatyupapattyupadeśa or Maraṇakșane Sugatiprāptyupadeśạ (by Mahāśikharadharmasvāmin); translation

Kalpaśamanopadeśa (by Vibhūticandra); translation

Dhyānasya Upadeśa (anonymous, if my understanding of the genitive is correct); translation

Cakrasamvarasya Yantram (anonymous); translation

an unnamed upadeśa (by Śāluguru); translation

Oḍiyānayantra (anonymous); translation

Prāṇāyāmadhāraṇayor Upadeśa (by Śrīvajrayoginī?); translation; incomplete

an Apabhraṃśa verse text, copied (?) and provided with interlinear notes

fol. $A^{v}+B^{r}$

Amarasiddheh Sārasamgrahaḥ (commentary on the Apabhraṃśa text); composed by Vanaratna on the basis of his own interlinear notes? 


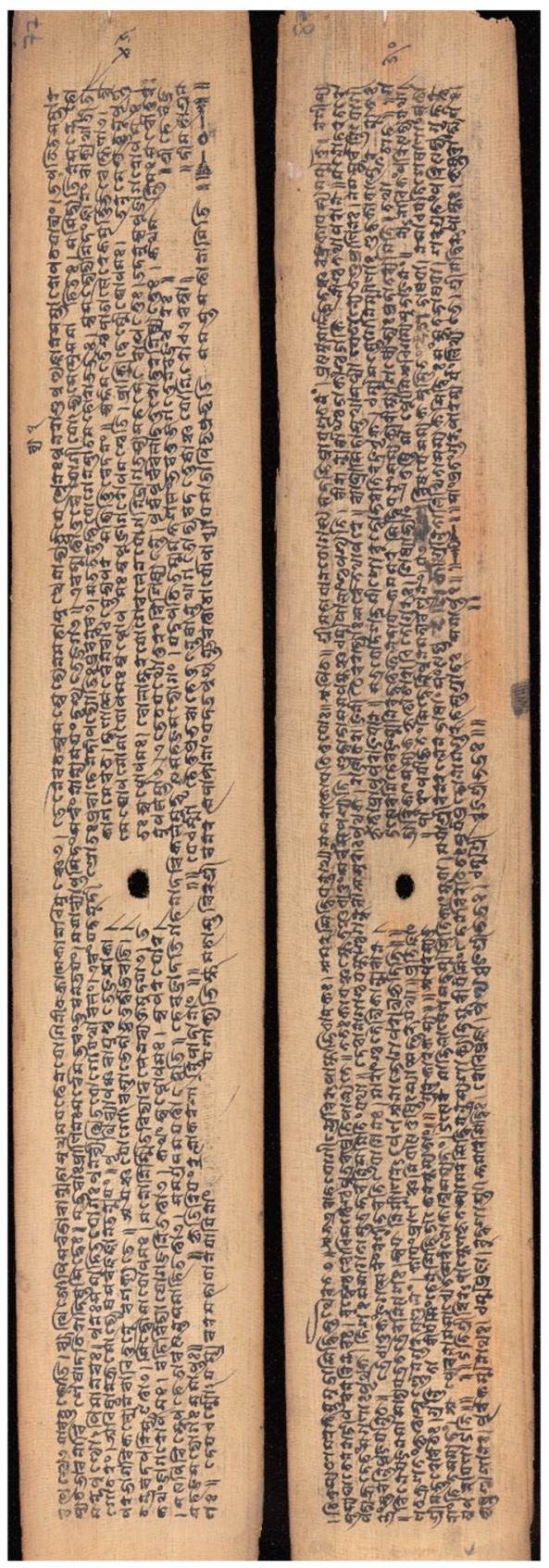

Fig. 1: Figs 1a and 1b: London, Royal Asiatic Society, Hodgson MS 35, fol. 45 (above/left) and fol. $50^{v}$ (below/right); courtesy of the Royal Asiatic Society. 
